\title{
Sex Sold in World Cities, 16oos-2ooos: Some Conclusions to the Project
}

\author{
Elise van Nederveen Meerkerk, Magaly Rodríguez García and \\ Lex Heerma van Voss
}

\section{Introduction}

In the general introduction to this volume, we justified our approach to analysing the global history of prostitution within a framework of a history of work and labour relations. In doing so, we are following the broad conception of work recently put forward by, among others, Marcel van der Linden. ${ }^{1}$ Global labour history aims to describe developments in labour relations over space and time, as well as to find explanations for the patterns that emerge. A comprehensive geographical and temporal perspective on the history of sex work is important because it can be placed in comparison with other forms of work that are, perhaps, more traditionally viewed as determining labour history, such as transport or factory labour. ${ }^{2}$ Therefore, this project was directed at asking the urban overviews' authors about the historical labour relations and working conditions of prostitutes, or sex workers, and how these changed over time. In this concluding chapter we would like to highlight what we think this approach has brought us and how it may help further the historiography of prostitution and the field of global labour history more generally. This will be done by emphasizing specific themes we outlined in our introduction, themes that formed the guiding principles of both the urban overviews and the comparative thematic papers in this volume.

When drawing general conclusions, it is of course impossible to do justice to all the rich and varied historical material that this volume has to offer. The aim

1 Marcel van der Linden, Workers of the World. Essays toward a Global Labor History (Leiden, 2008); Jan Lucassen (ed.), Global Labour History: A State of the Art (Bern [etc.], 2008); Andrea Komlosy, Arbeit: Eine globalhistorische Perspektive. 13. bis 21. Jahrhundert (Vienna, 2014).

2 Sam Davies et al. (eds), Dock Workers: International Explorations in Comparative Labour History, 1790-1970, 2 vols (Aldershot, 2000); Lex Heerma van Voss, Els Hiemstra-Kuperus and Elise van Nederveen Meerkerk (eds), The Ashgate Companion to the History of Textile Workers, 1650-200o (Farnham, 2010). 
of the project has been to gather local data in the urban overviews with the aim of comparing what has been brought to light through the thematic chapters that show the connections among them. It is our hope that others will use this collection for future comparisons as well. This final chapter focuses on several themes that in our opinion stand out from the contributions in this volume. Our goal is to systematically bring together some of these strands and sketch the patterns that appear over time.

First of all, this chapter relates the history of prostitution and prostitutes' experiences in terms of several broader developments in world history. Secondly, we stress the specifics of supply and demand in the labour market over space and time in relation to the history of prostitution. Thirdly, we think that the various ways societies and authorities have responded to prostitution and prostitutes constitute another important feature of how labour relations have developed in this type of work. Many of the thematic overviews in this volume indeed point to the strong relationship between various determinants of sex work such as legislation, labour relations, and working conditions. We aim to systematize these varying experiences in world cities over time, and we draw some general conclusions about the periodization of developments in the history of prostitution as we try to explain these patterns. Lastly, we briefly elaborate on how we think that the history of sex workers can enhance the study of global labour history.

\section{Prostitution and Structural Change}

Over the past four centuries, major socioeconomic changes have occurred. In this section we aim to analyse five of these changes that are closely related to each other: urbanization, industrialization, migration, colonization, and globalization. Although urbanization and migration existed before 1600 , these processes became all the more salient in the period investigated in this volume. While prostitution has historically occurred in the countryside, both the historiography and the chapters in this volume are in agreement that cities have usually been the nodal points of the sex trade due to their concentration of people and services. This is related to both the supply and demand of sex workers. On the supply side, cities in general offered more job opportunities, money, and other material benefits than the countryside, attracting many (often single) male and female migrants. ${ }^{3}$ As indicated in the chapters here,

3 See Hilde Greefs and Anne Winter, "Alone and Far from Home: Gender and Migration Trajectories of Single Foreign Newcomers to Antwerp, 1850-1880", Journal of Urban History, 42 (2016), pp. 61-80. 
a portion of the latter ended up in prostitution although they had not meant to do so when they migrated to the city, whereas other women intentionally sought the anonymity and grandeur of the urban environment to practise sex work. This is why, especially in the earlier period, most of the women who migrated to towns and became sex workers came from the (surrounding) countryside. Moreover, on the demand side, urban centres often provided a large clientele of single men such as sailors, soldiers, or migrant workers, as well as visiting businessmen and other short-term town dwellers, whether single or married, who were looking for sexual pleasure during their stay. Since the late nineteenth century, cheaper transport and the rise of mass tourism have provided both sex workers and clients with the means to have sexual encounters in cities far away from their places of origin. ${ }^{4}$

Not coincidentally, in many colonized societies encounters with European colonizers brought about the inhabitants' first experiences with urbanization as well as with prostitution in the form that was known in the "west" as well as with "western" forms of sexual-affective exchange. ${ }^{5}$ In the world outside of Europe, a vast, diverse set of sexual arrangements existed, many of which involved the exchange of money or material goods for sex. As the European colonial system invaded and/or co-opted these, sexual exchanges became reclassified according to European moral schemata. This transformation was also shot through with increasingly influential ideologies of blood purity and race, literally denigrating (in the sense proposed by Frantz Fanon) sexualaffective unions between Europeans and "natives". ${ }^{6}$ In first instance, mainly white men-either temporarily or permanently — migrated to the overseas territories from the metropolis, and many of them had paid (monetary or otherwise) sexual encounters with indigenous women. The foot soldiers of the colonial armies were often non-white men from other parts of the colonial empires, and the same held true for them. In the course of the nineteenth century, with the increasing settlement of European men and later women in the colonies, interracial sexual relationships increasingly became a great concern for colonial states. Symbolically, one of the means of dealing with this "problem" was related to the urban environment. As Liat Kozma notes, colonial authorities deliberately started to design the urban spaces of newly established colonial towns with the aim of segregating their inhabitants along the lines of

4 Keusch, this volume, Migration.

5 See Raelene Frances, "Prostitution: The Age of Empires", in Chiara Beccalossi and Ivan Crozier (eds), A Cultural History of Sexuality in the Age of Empire (Oxford [etc.], 2011), pp. 145-170.

6 Frantz Fanon, Peau noire, masques blancs (Paris, 2001). We owe this suggestion to Thad Blanchette. 
race, class, and "respectability". ${ }^{7}$ The contributions to this volume make it quite clear that processes of urbanization, migration, and colonialism generally contributed to the rise and expansion of prostitution.

Another very important development that accelerated from the eighteenth century onwards was industrialization. Although scholars in the past have pointed to the relationship between industrialization and the occurrence of prostitution, ${ }^{8}$ we believe that this relationship is far from clear-cut. ${ }^{9}$ For one thing, both pre-industrial and early industrializing European and newly emerging colonial towns can, overall, hardly be called centres of booming industrialization. Much of the first industrialization in Europe took place in (semi)rural areas, and presumably colonialism even led to de-industrialization at least into the late $1900 .^{10}$ Large cities had historically been centres of commerce and services that were complemented with small-scale artisanal production. As mentioned already, the service-oriented and recreational aspects of towns attracted both migrant women looking for work and clients looking for pleasure rather than mere industrial activities (and this continues up to the present day). Admittedly, from early on towns enjoyed a relatively high amount of monetary circulation and wages were higher than in the countryside, but this had already been the case long before industrialization. ${ }^{11}$ More indirectly, perhaps, industrialization may have contributed to the rise of sex work as it stimulated monetization, urbanization, migration, and population growth in general. But in our view, the process of industrialization cannot be considered to be one of the main driving forces behind increases of prostitution.

Lastly, the process of globalization is worthy of attention. Recent years have witnessed animated debates about globalization and these have centred on the following questions: When did it begin? How should we define it? And,

$7 \quad$ Kozma, this volume, Colonial Relations.

8 See Ruth Rosen, The Lost Sisterhood: Prostitution in America, 1900-1918 (Baltimore [etc.], 1982), pp. 3-4; Victoria Harris, Selling Sex in the Reich. Prostitutes in German Society, 19141945 (Oxford, 2010), pp. 46-55; Lex Heerma van Voss, "The Worst Class of Workers: Migration, Labor Relations and Living Strategies of Prostitutes around 190o", in Marcel van der Linden and Leo Lucassen (eds), Working on Labor: Essays in Honor of Jan Lucassen (Leiden, 2012), pp. 153-170, 159 .

9 Magaly Rodríguez García, "Ideas and Practices of Prostitution around the World", in Paul Knepper and Anja Johansen (eds), The Oxford Handbook of the History of Crime and Criminal Justice (New York, 2016), pp. 132-154.

10 Jeffrey G. Williamson, Trade and Poverty. When the Third World Fell Behind (Cambridge, MA [etc.], 2013).

11 Robert Allen, The British Industrial Revolution in Global Perspective (Cambridge, 2009). 
how can we measure it? ${ }^{12}$ Regardless of whether we decide to adhere to the broader definition of globalization, including the worldwide cultural, economic, and even ecological convergences that have taken place since the "Columbian Exchange", or hold to a stricter, more economy-based definition that references low transport costs and market integration, it is clear that in both cases globalization has historically had a tremendous influence on sex workers. As, for instance, the many contributions to this volume on Latin America show, the first encounters with the Spanish and Portuguese conquerors around the year 1600 dramatically changed indigenous societies, leading to previously unknown forms of sexual exchange and inscribing known ones with a European moral matrix.

Later waves of globalization dramatically lowered transport costs, leading to long-distance migration which prompted women to move greater distances, while at the same time raising completely new concerns related to sex work such as "white slavery" and human trafficking. While the percentage of migrants seems to be over-represented in the (past and present) population of sex workers in comparison to the share of migrants in the population as a whole, clearly globalization has significantly increased the proportion of migrants. ${ }^{13}$ In fact, it can be argued that patterns of female migration across national borders, as noted by Nicole Keusch in this volume, at least from the nineteenth century onwards fit the chronology of "waves of globalization" (expansion from ca. 1850-1914, contraction between 1914 and ca. 1950, and again expansion since the 196os) rather well. In the nineteenth and early twentieth centuries, this especially concerned European women travelling to other parts of the world, Chinese women travelling to the Us, and Japanese women going to other parts of Asia. The more recent wave of globalization conversely shows a trend of women from the "Global South" travelling to the "Global North".14

Both strands of migration seem to have run parallel with preoccupations of a moral, ethical, and racial nature, and more generally with concerns about

12 See Jeffrey G. Williamson and Kevin O'Rourke, “When Did Globalisation Begin?” European Review of Economic History, 6 (2002) pp. 23-50; Dennis O. Flynn and Arturo Giraldez, "Path Dependence, Time Lags, and the Birth of Globalization: A Critique of O'Rourke and Williamson", European Review of Economic History, 8 (2004), pp. 81-108; Jan de Vries, "The Limits of Globalization in the Early Modern World", Economic History Review, 63 (2010), pp. $710-733$.

13 Nevertheless, although migrants are and have always been over-represented in the population of prostitutes compared to the total population, we should also remember that the majority of sex workers generally have been non-migrants or rural-urban migrants. Mechant, this volume, Social Profiles.

14 Keusch, this volume, Migration. 
public safety and organized crime. As more women migrated alone and across long distances, which removed them from their families' sexual-economic control and protection, it was to be expected that this would lead to charges of sexual immorality as well as cases of abuse. It is possible that during the first wave (1850-1914) these concerns were more likely expressed by stressing the alleged victimhood of white women and by scapegoating Jewish people,$^{15}$ while in the second wave (since 1960), concerns have more often been connected to issues of unwanted non-western immigration and the stereotyping of eastern European and non-European women (as victims) and men (as perpetrators). Furthermore, globalization has also brought about new forms of communication, such as the telephone and the internet. These technical developments have enlarged the scope and capabilities of sex workers worldwide and considerably changed the features of the trade, as many of the chapters in this volume emphasize. ${ }^{16}$

\section{Labour Relations and Labour Market Dynamics}

As mentioned above, we do not believe that it was industrialization per se but rather urbanization and the (monetary) labour opportunities towns offered that stimulated the engagement of women in sex work. While monetization and wage dependence are not necessarily linked to prostitution — as many other forms of sexual exchange existed and still exist, such as bartering or sex in return for certain privileges-it is clear that an increasing dependency on money/wage labour has influenced the history of labour relations in prostitution. For instance, while a whole spectrum of labour relations, ranging from slavery and reciprocal labour to independent remunerated labour, has existed throughout history, those prostitutes working for someone in return for wages, or for their "own wages" (e.g. self-employed), have generally been better off than prostitutes in any other form of labour relation. Moreover, in recent decades, self-proclaimed sex workers have staked the claim that they are selling a service for a wage (their own), allowing them to more collectively organize and demand workers' rights and entitlements such as written contracts, health

15 Magaly Rodríguez García, "The League of Nations and the Moral Recruitment of Women", International Review of Social History, 57 (2012), pp. 97-128; Paul Knepper, "British Jews and the Racialisation of Crime in the Age of Empire", The British Journal of Criminology, 47 (2007), pp. 61-79.

16 See Ekpootu, this volume, Nigeria; Frances, this volume, Working Conditions; Keusch, this volume, Migration. 
and social benefits, and protection from violence at the hands of the state and abusive employers or clients. ${ }^{17}$ Nevertheless, as demonstrated in most of the urban as well as thematic overviews in this volume, prostitution has almost never been considered to be "normal" work, not by the authorities, not by society, and perhaps not by many prostitutes themselves.

A recurrent theme in many of the papers is the role of segmentation in the labour market. In most of the periods and regions analysed in this volume, both gender and ethnicity have significantly influenced labour market opportunities for women in general and for migrant women in particular. Historically, gender discrimination against women has been almost omnipresent, and this was not in the last place expressed in terms of unequal labour relations and restrictions for women in the labour market. ${ }^{18}$ The limited prospects women have faced in the labour market throughout most of history have led some of them to deliberately choose sex work in order to make a living during at least part of their lives. Less fortunate women may have been directed towards prostitution out of sheer poverty and lack of alternatives, and/or by force. Many of the chapters in this volume show that throughout most of history, women have been crowded into a small number of poorly remunerated and often precarious jobs, such as domestic service, textile work, and small-scale retailing. In contrast, as Raelene Frances notes in her overview on working conditions, across space and time many prostitutes were able to earn significantly more than women could in most other jobs. Although it is difficult to generalize because the circumstances in which women worked have varied substantially, for one sexual exchange they could often obtain the same amount of money that unskilled male labourers earned in a day. ${ }^{19}$ So, even if some women initially did not become sex workers of their own free will, many of them may have decided to stay in the business because of a lack of equally rewarding options and because in most cases they had already suffered shame and been branded for doing something illegal or "immoral". Moreover, many prostitutes seem to have preferred prostitution to other occupations which were not only badly paid but also exhausting and often dangerous. "Ordinary" work outside the sex trade often also involved rendering sexual services, as sexual harassment was (and still is) fairly common in domestic and factory work, as well as in the retail sector and the entertainment industry. ${ }^{20}$

\footnotetext{
17 Pluskota, this volume, Labour Relations.

18 Van Nederveen Meerkerk, this volume, Gender.

19 Frances, this volume, Working and Living Conditions.

20 Rosen, The Lost Sisterhood, pp. 152-154. See also Dasgupta, this volume, Calcutta.
} 
It is difficult to pinpoint patterns of labour relations in the history of prostitution. As Pluskota notes, all kinds of labour relations have existed and still exist in the business. While past and present concerns about trafficking certainly have carried harsh political and moral connotations, ${ }^{21}$ it is undeniable that various women have been, and are, experiencing forms of sex slavery. More subtle forms of coerced and unfree labour relations occur when family members drive their wives or daughters into sex work. ${ }^{22}$ Yet even in situations which fit the definition of "forced prostitution" or "trafficking", some women do not seem to have resisted being pawned off or even sold, as working on behalf of their families can be construed to be a form of filial piety. ${ }^{23}$

Most prostitutes do not seem to have been enslaved. Rather, they seem to have worked either with a mediator or independently, receiving part of or all of their clients' payments. There are at least three frequent combinations that seem to have occurred in most of the societies we have scrutinized in this volume, some of them in the early modern period and others only occurring in later periods, for instance in the process of colonization and its accompanying urbanization. These include streetwalking with a pimp, streetwalking or working from home without a pimp, and small-scale brothels run by a madam. ${ }^{24}$ In cases when prostitutes worked for pimps or madams, they would generally have to give a rather large share of their earnings, usually ranging from one- to two-thirds, to the person for whom they worked. Although this did often lead to exploitation - as in the case of labour relations resembling debt bondage, or if a pimp or madam tried to keep prostitutes addicted to drugs or alcoholworking in a brothel or for a pimp could also mean real protection and even involve affective relationships. ${ }^{25}$

The labour relations and working conditions associated with prostitution have been closely related to the ways in which society, and especially the authorities, have responded to sex work. As Pluskota shows, working in a tolerated or regulated brothel can provide a certain amount of security for sex workers. From the nineteenth century onwards, regulation also brought about a situation in which formerly independent prostitutes lost much of their leeway and bargaining power because they were confined to particular urban spaces; in addition, they were forced to register and were monitored in

\footnotetext{
21 See Rodríguez García, "The League of Nations"; Blanchette, this volume, Agency.

22 Pluskota, this volume, Labour Relations.

23 Heerma van Voss, “The Worst Class of Workers", pp. 164, 168.

24 "Streetwalking" can also involve soliciting at public establishments like cafés, restaurants, and theatres.

25 Van Nederveen Meerkerk, this volume, Gender.
} 
numerous aggressive ways. ${ }^{26}$ But as Pascale Absi and Raelene Frances argue in their contributions to this volume, while it is true that most women scorned the mandatory health controls and medical treatment common in the regulated brothels of the nineteenth and twentieth centuries, many also seem to have used their contacts with doctors and social workers for their own personal ends (e.g. to receive treatment for medical issues aside from venereal diseases or to exit the milieu of prostitution). Also, the heightened awareness about venereal diseases that accompanied the regulation system probably benefited many women involved in prostitution. ${ }^{27}$ Nonetheless, this system was largely perceived as being draconian. Therefore, many prostitutes in regulationist cities opted for clandestine prostitution, even if this meant an increased danger of prosecution and even violence at the hands of the police.

Generally, we can conclude that the (positive or negative) effects of regulation or tolerance on the labour relations and working conditions in the sex trade have varied according to the way prostitution has been perceived by the authorities across time and space. When prostitution was understood to be a "necessary evil", policies and working conditions seemed to have been fairly relaxed; if prostitution was defined in terms of deviancy and harmful or dangerous behaviour, harsh measures were the rule, labour relations deteriorated, and (exploitative) intermediaries started to play a more prominent role; and when prostitution came to be treated as a form of work, policies have become far less repressive and have granted more benefits to sex workers. In several cities, a mixed reading of prostitution seems to have existed (and still exists), resulting in equally mixed policies and working conditions. The emphasis on the importance of authorities' dealings with prostitution leads us to the final important category of analysis in this conclusion: state and non-state actors' responses to sex work.

\section{Responses to Prostitution}

With some exceptions, most forms of prostitution have been morally and/or legally condemned in the time periods and regions under study here. In most early modern European towns, it was not prostitution as such that was considered to be a vice but, more broadly, extra-marital sexual relationships that were often referred to as "adultery" or "fornication". While in some settings, such as pre-industrial China, high-echelon prostitutes may to a great extent have been

26 Pluskota, this volume, Labour Relations.

27 Absi, this volume, Bolivia; Frances, this volume, Working Conditions. 
accepted and even gained considerable social status, more frequently prostitution was seen as "evil", albeit perhaps often a necessary evil. Prostitution was tolerated or even regulated in many cities until around the sixteenth century because prostitutes supposedly served as outlets for men's sexual drives and protected "honest" women from rape. Cultural, politico-military, and socioeconomic changes from the late fifteenth century onward altered perceptions of prostitution and, above all, government responses to it. Parallel to the religious revival of the time, an increased number of unregulated prostitutes became visible. As the early modern state and its large military apparatus developed, independent prostitutes started following the armies. This new situation led to a spread of venereal diseases and the authorities reacted with the adoption of ordinances prohibiting prostitution and confining women in hospitals or prisons. Religious societies also became increasingly involved in campaigns against prostitution and in rehabilitation programmes for "fallen women". ${ }^{28}$ Hence in the seventeenth and eighteenth centuries prostitution was likely to be either criminalized and intensively persecuted by both civic and religious authorities, or tolerated but only to a certain extent. Regulation was rare until the late eighteenth century, as seen in graph 33.1. In north-western European towns such as Amsterdam and London, which attracted large numbers of sailors and other migrants, tolerance was the most natural response, even though prostitutes could easily be arrested if they were suspected of improper or subversive behaviour. ${ }^{29}$ In most other European towns, however, procuring, brothel-keeping, and/or prostitution were against the law and sometimes dealt with in a harsh manner. Interestingly, many non-European pre-industrial towns, particularly in North Africa and Asia, seem to have been relatively more tolerant regarding sexual services up until the nineteenth century, with the notable exception of Hanoi.

Graph 33.1 systematizes the patterns of authorities' dealings with prostitution and prostitution-related activities over time in the cities included in this project. ${ }^{30}$ There is immense complexity in the transitions from one kind of response to another, and these do not seem to have been quite synchronous for any of the towns and cities in our sample. On the other hand, if we look at specific periods in history, we can indeed discern distinctive similar responses

28 Rodríguez García, "Ideas and Practices of Prostitution around the World".

29 See Lotte van de Pol, The Burgher and the Whore: Prostitution in Early Modern Amsterdam (Oxford, 2011). See also Pluskota, this volume, Amsterdam. Pluskota attributes the relative ease with which prostitutes were arrested in early modern Amsterdam to the town's distinct Calvinist culture.

For a discussion of the graph see the appendix. 


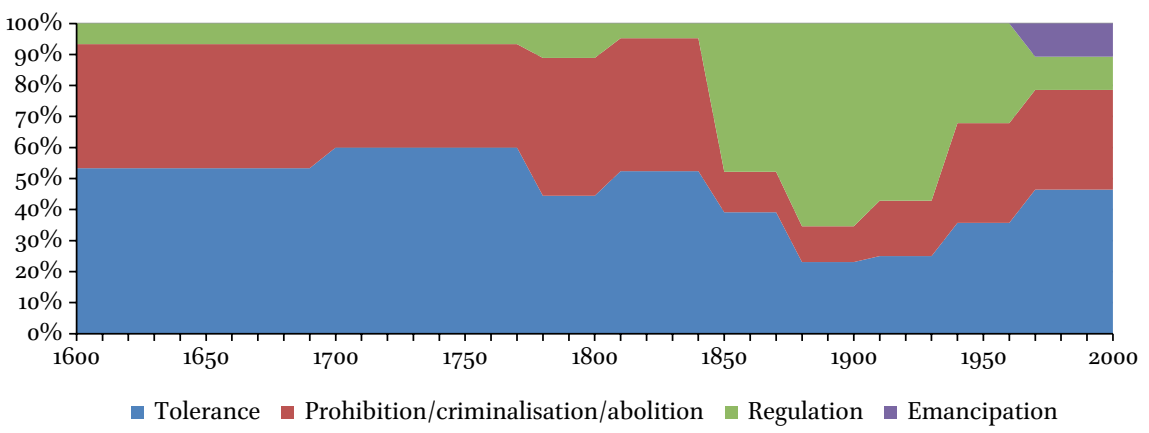

GRAPH 33.1 Trends in legislation, $1600-2000$

SOURCE: BASED ON TABLE 33.1 (APPENDIX)

to prostitution on a global scale, and the overall picture is rather simple. These responses link up to the specific contextual developments mentioned earlier in this chapter which steered urban or national authorities towards a particular reaction to prostitution. Before the second half of the nineteenth century, the two most common approaches were prohibition/criminalization or tolerance. Quite often, prostitution was formally forbidden in either case, and the difference was whether the authorities made an effort to stamp out the practice or thought it better to supervise and therefore tolerate it at least under certain circumstances (only in special neighbourhoods or via certain ways of advertising the business and soliciting clients). In the course of the nineteenth century, the combination of the emergence of the nation-state and processes of globalization and colonialism led to increased awareness and anxiety concerning uncontrolled sexuality, and this in turn led to an increase in regulation. Regulation had started in (post)revolutionary France and it was to a large extent concerned with the formation of a nation-state in which information about the population was meticulously kept and the goal was to increase the health of its citizens. Consequently, a system of regulation came into being which, not coincidentally, elsewhere was often referred to as the "French System".

While many towns in Europe and the Americas adopted the regulated system during the second half of the nineteenth century, the regulations forced upon colonial settings by imperial powers were particularly harsh. In the 186os, the British introduced the Contagious Diseases Acts in garrison towns and abroad. The measures were specifically intended to secure the imperial project and combat the consequences of prostitution to protect British troops. The system never extended to the metropolis as a combination of informal regulation and repression continued to be practised in London throughout the 
nineteenth century. ${ }^{31}$ In the colonies, the regulation of prostitution served a dual goal: on the one hand, protecting colonial soldiers and settlers from venereal diseases, and on the other hand, controlling interracial sexual encounters, which were of increasing concern to many imperial rulers. ${ }^{32}$ As Kozma argues, while in Europe regulation came under increasing criticism at the end of the nineteenth century, in the colonies it was deemed to be unavoidable. ${ }^{33}$

Whereas in earlier periods the image of the prostitute as a deviant or "fallen woman" had prevailed, towards the end of the nineteenth century the idea of (especially white) women as victims of procurers and traffickers emerged. The abolitionist movement may have gotten started in Great Britain but over time it was increasingly supported worldwide by the emerging feminist movement. Around the turn of the century, the International Bureau for the Suppression of Traffic in Women and Children was established, and it condoned state-regulated prostitution but strove to repress the international "white slave traffic". In the early twentieth century the first conventions against trafficking were adopted, but it appeared that they were often not observed, so the League of Nations in the early 1920s assembled a committee to investigate and discuss the international traffic of women which came to be linked to the regulation system. ${ }^{34}$ As Table 33.1 in the appendix shows, these international activities inspired many countries to draw up abolitionist legislation, even if it sometimes took decades for those laws to be implemented. The authorities in many towns only enforced legislation against activities that facilitate prostitution (pimping, soliciting, brothel keeping and so on) in the two decades after the Second World War, although prostitution itself was not criminalized.

For many decolonizing countries, the abolition of the regulation system may not have followed so much from concerns about international campaigns against trafficking but rather constituted a reaction to the old colonial relations that were felt to have introduced despised western morals to overseas territories, and those relations were then targeted for eradication. Another important development in this respect was of course the rise of communist regimes that viewed prostitution as a detrimental result of the capitalist system which, it was argued, had to be eliminated either by re-education or repression. The Soviet Union for instance explicitly decriminalized prostitution in 1918, removing any reference to it from their first Criminal Code. All through

31 Laite, this volume, London; Kozma, this volume, Colonial Relations.

32 Ann Laura Stoler, Along the Archival Grain: Epistemic Anxieties and Colonial Common Sense (Princeton, 2009), esp. Chapter 3, pp. 57-104.

33 Kozma, this volume, Colonial Relations.

34 Rodríguez García, “The League of Nations”, pp. 101-104. 
the 1920 s the official line (pursued by the central ministries against recalcitrant local governments) was that prostitution was not a crime but pimping was. This never changed. However, at the same time the police (or N KVD) arrested prostitutes as "socially harmful elements" and for "hooliganism". In the table, we have classified as criminalization this practice of de facto persecuting what was not de jure illegal for Moscow, St. Petersburg, Shanghai, and Havana after their respective transitions to the communist system. In the non-communist world, the only country that opted for the outright prohibition of prostitution was the United States, which launched its prohibitionist policies in 1919. As in other prohibitionist areas, the criminalization of prostitution in Us cities (except for the state of Nevada) led to harsh measures against sex workers and drove the sex trade underground.

These broad categories also make it possible for us to look at the four regional blocks in which we have organized the urban overviews in this volume. These are commonly used geographical units: Europe, Africa and the Middle East, the Americas, and Asia-Pacific. In Table 33.1 in the appendix we compare nine European towns, six towns in Africa and the Middle East, six towns in the Americas and six Asian-Pacific towns. ${ }^{35}$ As some of the overviews do not treat the earlier period, over time the total number of observations grows from fifteen in the seventeenth and eighteenth centuries to twenty-eight in the twentieth century. Can we distinguish different patterns for these four large areas? As we noted before, the dominant responses to prostitution in the seventeenth and eighteenth centuries on a global scale were tolerance and prohibition. But in Europe prohibition was fairly common, while Latin America and Asia-and to a lesser extent Africa-showed strong traditions of tolerance. Regulation in these two centuries was limited to a small number of towns (Florence, Paris and Cairo). However, from the mid-nineteenth century onward it became the trend in Europe, followed, with a time lag of only a few decades, by the rest of the world. Regulation remained the dominant system globally from the 185 os until the 1930s. The rest of the twentieth century saw formal abolition and tolerance or de facto regulation on the rise, followed from the 1970s by a few areas of emancipation. This movement was carried on by Latin America reverting to its tradition of tolerance and Europe becoming dominantly tolerant of prostitution for the first time in the modern period. The areas of emancipation are found in Australia and Europe. In terms of continents, Europe often stands out: first by a relative preference for prohibition (shared by

35 The total differs from the number of chapters as some chapters deal with more than one town and not all cities for which information was collected in the project are included in the publication. 
the Middle East), then by a strong preference for regulation spread around the world through European colonialism and more recently by legalization or various shades of abolitionism (ranging from tolerance to the criminalization of clients).

Globalization and decolonization in the past few decades have stimulated the migration of women from the Global South to the Global North, and a number of those women have engaged in prostitution. Likewise, the fall of the Soviet Union stimulated the migration of eastern European sex workers to destinations all over the world. ${ }^{36}$ These changes, together with a more general tendency to liberate women's sexuality (at least in the western world following the second feminist wave), have since the 197os led to a shift from abolition to at least forms of tolerance or, in a few instances, to the legalization of sex work. We can clearly see this illustrated in table 33.1 for towns in Europe such as Amsterdam and Florence and for towns in Latin America, Africa, and Australia. In places where prostitution is now legal and regulated, the working conditions for sex workers seem to have improved (although the stigma remains), as they are entitled to the same benefits as other citizens in the labour market. ${ }^{37}$ Yet parallel to the growth of the sex workers' movement is the re-emergence of the abolitionist/prohibitionist discourse and the strengthening of networks and campaigns against human trafficking and so-called modern slavery. The idea of prostitutes as victims has been emphasized and has led to alternative legislative ways to repress prostitution. At the end of the 1990s, Sweden became the first country to criminalize the purchasing of sex. Throughout the first decades of the twenty-first century, several countries have followed the Swedish example. In 2014, the European Parliament approved a non-binding resolution which recommends that EU countries re-evaluate their sex work policies so they can reduce demand for prostitution and trafficking by punishing clients.

In all these patterns of dealing with prostitution, labour relations in the business have been very much influenced by the way state or urban authorities set the legal framework. Some examples were already given in the previous section. Being a self-employed prostitute does not necessarily mean that one is better off because a woman may need the protection of a pimp or madam.

36 Keusch, this volume, Migration.

37 Alexis A. Aronowitz, "To Punish or Not to Punish: What Works in the Regulation of the Prostitution Market”, in Nina Peršak and Geert Vermeulen (eds), Reframing Prostitution: From Discourse to Description, from Moralisation to Normalisation? (Antwerp, 2014), pp. 223-251, 242. 
Especially if prostitution is illegal, self-employed sex workers-particularly streetwalkers-face harassment not only by clients but also by the police. On the other hand, when prostitutes work under wage-dependent, debt bondage, or coerced labour relations in the contexts of abolition or prohibition, they are even more at the mercy of their pimp or madam because of their illegal status. This also goes for present-day illegal migrant women who may be drawn into criminal networks because of their vulnerable position. In cities where sex workers operate in a legal environment, illegal prostitution has not entirely disappeared. Illegal migrants still experience the detrimental effects of clandestine prostitution. It is, however, clear that the position of prostitutes on the whole is most favourable when prostitution is legal and when individuals are (relatively) free to enter or leave any occupation they prefer. ${ }^{38}$

\section{Sex Work and Global Labour History}

In this volume we have studied the history of prostitution in world cities within the scope of work. Even if, as some feminist scholars and activists have fiercely argued, all forms of prostitution should be seen as sexual slavery - a view we do not endorse - it deserves to be studied from a labour history perspective because the broad definition of work includes all forms of labour, also slavery. ${ }^{39}$ In this final section, we wish to establish what such a long-term and worldwide analysis of sex work adds to our knowledge of labour relations more generally and how it may enrich the perspective of global labour history.

Throughout history, prostitutes have offered a service that many may have considered to be aberrant or even "evil" but for which there has been demand in all regions of the world in the entire period studied here. Sex workers have received compensation for these services, be it monetary or non-monetary. In recent decades, they have started organizing as workers and correspondingly demanded workers' rights, entitlements and-perhaps just as importantlyrecognition by society and the state. Nevertheless, prostitution up until today has never been considered to be "normal" work, even in those few places where it has been legalized. ${ }^{40}$ Moreover, prostitution, or facilitating it, has often been

38 Barbara Sullivan, "Rape, Prostitution and Consent", Australian and New Zealand Journal of Criminology, 40 (2007), pp. 127-142.

39 Van der Linden, Workers of the World.

40 Aronowitz, "To Punish or not to Punish", pp. 223-256. 
criminalized, thus giving it a connotation of crime rather than of work. This distinguishes it from a range of other occupations and sectors that have been scrutinized by labour historians over the past few decades.

What sets prostitution apart from many other forms of labour is that it is highly sexualized and highly gendered. ${ }^{41}$ As some authors in this volume have argued, sexual services have often been considered to be a "natural duty" that women should perform for men, and some prostitutes themselves have at times even compared being married to fulfilling unpaid sexual services. ${ }^{42} \mathrm{In}$ this respect, sex workers can perhaps most adequately be compared to domestic workers who, for a very long time, have also been largely ignored as true workers by society, the state, and much of labour historiography. ${ }^{43}$ Domestic work has also often been seen as the natural calling of women, particularly wives, and has accordingly been undervalued and under-represented in the labour movement and historiography.

However, what distinguishes prostitution from domestic work is that it has in many instances been one of the few occupations in which women, at least for a certain phase in their life cycle, could earn a relatively reasonable to decent living, sometimes even exceeding the income of men in many occupations. In fact, if one looks at the alternatives women had in the labour market in most of history, prostitution was often the only viable way to make a living for women, either because they were excluded from many occupations as females (and migrants) or because the alternatives they had just did not yield sufficient incomes. A broader lesson to be learned from this is that labour historians, when exploring the global history of work, should be careful not to isolate a particular occupation or sector in their analysis of labour relations and they should always take into account the wider labour market dynamics pushing some groups of women, and also men, into particular forms of work which may seem unreasonably dangerous or unattractive. ${ }^{44}$

Apart from the (often local) conditions in the labour market, it is clear that more universal developments in history have also had a major impact on

41 Of course, throughout history there have always been male prostitutes, but they were and still are generally a minority.

42 See Wyers, this volume, Istanbul; Dasgupta, this volume, Calcutta; Van Nederveen Meerkerk, this volume, Gender.

43 See Dirk Hoerder, Elise van Nederveen Meerkerk and Silke Neunsinger (eds), Towards a Global History of Domestic and Care Workers (Leiden, 2015).

44 One can think of the health risks involved in mining or some professional sports which are well known to the workers concerned and still many people worldwide are drawn to those professions. 
labour relations in prostitution. Here, we have identified three larger processes in particular: urbanization, globalization, and colonization. These three developments were highly interrelated and also link up to the fact that a considerable proportion of sex workers (though usually not the majority) have been migrant women. Together with the processes of urbanization and globalization, migration has tended to become more important and be performed over longer distances. The (lack of) opportunities that migrants, especially migrant women, have had in the receiving labour market and more generally their relatively vulnerable positions in the society they arrived in have determined to a large extent the labour relations and conditions in which they worked.

However, as most of the chapters in this volume show, it would be a major error, even a distortion of history, to view migrant sex workers solely as passive victims. In the case of migration, many women have known, or at least suspected, what they were getting into, and even if it was because of lack of alternatives, many of them seem to have weighed the advantages against the disadvantages of prostitution and deliberately chosen to become sex workers. After all, not all (migrant) women end up in prostitution, even if they too live under similar miserable economic conditions and have limited choices in the labour market. Moreover, whereas some women have indeed been forced or lured into prostitution, this does not mean that they could not exert any control over their own lives after they found themselves in an unfavourable position. The contributions in this volume show that many prostitutes have had a considerable - although varying — degree of agency in deciding about their working lives. This leads us to the final point we would like to make with this global history of sex workers: labour historians should try to move away from simple dichotomies between "coercion" and "voluntarism" and instead focus on the degrees of freedom that workers have had in the past and present. ${ }^{45}$ This holds true for many other occupations aside from prostitution.

45 Robert J. Steinfeld and Stanley L. Engerman, "Labor-Free or Coerced? A Historical Reassessment of Differences and Similarities", in Tom Brass and Marcel van der Linden (eds), Free and Unfree Labour: The Debate Continues (Bern, 1997), pp. 107-126. For a conceptual overview of the boundaries of "free" and "coerced" labour in international law, see Magaly Rodríguez García, “On the Legal Boundaries of Coerced Labor”, in Marcel van der Linden and Magaly Rodríguez García (eds), On Coerced Labor: Work and Compulsion after Chattel Slavery (Leiden, 2016), pp. 11-29. 


\section{Appendix: Data for Graph 33.1}

TABLE 33.1 Trends in legislation, $1600-2000$

\begin{tabular}{|c|c|c|c|c|}
\hline & 17th century & 18th century & $1780 s-1800 s$ & $1810 s-1840 s$ \\
\hline Tolerance & $\begin{array}{l}\text { Amsterdam } \\
\text { Cairo } \\
\text { Calcutta } \\
\text { Havana } \\
\text { Bruges } \\
\text { London } \\
\text { Mexico } \\
\text { Shanghai }\end{array}$ & Paris & $\begin{array}{l}\text { Sydney } \\
\text { Johannesburg }\end{array}$ & $\begin{array}{l}\text { Chicago } \\
\text { Florence } \\
\text { Moscow } \\
\text { Rio de Janeiro } \\
\text { Jaffa }\end{array}$ \\
\hline $\begin{array}{l}\text { Prohibition/ } \\
\text { criminal- } \\
\text { ization/ } \\
\text { abolition }\end{array}$ & $\begin{array}{l}\text { Hanoi } \\
\text { Istanbul } \\
\text { Moscow } \\
\text { Paris } \\
\text { Vienna } \\
\text { Stockholm }\end{array}$ & $\begin{array}{l}\text { Moscow } \\
\text { St. Petersburg } \\
\text { Stockholm }\end{array}$ & $\begin{array}{l}\text { Amsterdam }^{\mathrm{a}} \\
\text { Florence } \\
\text { Bruges }\end{array}$ & $\begin{array}{l}\text { Cairo } \\
\text { Havana }\end{array}$ \\
\hline Regulation & Florence & & $\begin{array}{l}\text { Cairo } \\
\text { Paris }\end{array}$ & \\
\hline
\end{tabular}

Emancipation

Note: City names in italics designate attitudes to procuring, brothel keeping etc., not to prostitution per se.

$\mathrm{a}=$ procuring; $\mathrm{b}=$ procuring by men; $\mathrm{c}=$ brothel keeping; $\mathrm{d}=$ radical; $\mathrm{e}=$ independent sex work; $\mathrm{f}=$ restricted areas; $\mathrm{g}=$ clients; $\mathrm{h}=$ formally tolerated but subjected to much police harassment based on other legislation SOURCE: CHAPTERS IN THIS VOLUME. 


\begin{tabular}{|c|c|c|c|c|}
\hline $1850 s-1870 s$ & $1880 s-1900 s$ & $19105-19305$ & $1940 s-1960 s$ & $19705-2000$ \\
\hline Havana & & Stockholm & Amsterdam & Bruges \\
\hline \multirow[t]{14}{*}{ Perth } & & & Paris & Florence \\
\hline & & & Tel Aviv & Johannesburg \\
\hline & Rio de Janeiro ${ }^{\mathrm{e}}$ & Rio de Janeiro & & $\mathrm{La} \mathrm{Paz}$ \\
\hline & & & Buenos Aires & Mexico city \\
\hline & & Moscow $^{h}$ & & Perth \\
\hline & & St. Petersburgh & & \\
\hline & Amsterdam & Chicago & Cairo & Paris \\
\hline & Chicago $^{\mathbf{a}}$ & Calcutta & Casablanca & Stockholm \\
\hline & Rio de Janeiro $^{\mathrm{c}}$ & Johannesburg ${ }^{\mathrm{d}}$ & Hanoi & Vienna $^{\mathrm{a}}$ \\
\hline & Vienna & Moscow $^{h}$ & Havana & \\
\hline & Sydney ${ }^{\mathrm{b}}$ & St. Petersburgh & London & \\
\hline & & Singapore & Mexico City & \\
\hline & & & Shanghai & \\
\hline & & & $T e l A v i v^{\mathrm{a}}$ & \\
\hline Calcutta & Buenos Aires & Casablanca & Singapore & \\
\hline Florence & Cairo & Lagos & & \\
\hline Mexcio City & Hanoi & Perth & & \\
\hline Stockholm & Istanbul & & & \\
\hline Vienna & Johannesburg & & & \\
\hline Singapore & $\mathrm{LaPaz}$ & & & \\
\hline Moscow & Shanghai & & & \\
\hline St. Petersburg & Tel Aviv & & & \\
\hline \multicolumn{5}{|l|}{ Bruges } \\
\hline & & & & Amsterdam \\
\hline & & & & Sydney \\
\hline & & & & Vienna \\
\hline
\end{tabular}




\section{Comments on the Table}

For each town and period for which information is given in the urban overviews, we have classified the position of the authorities towards prostitution into one of four categories: tolerance, prohibition/criminalization/abolition, regulation or emancipation. It is not so easy to define precise borders for these categories, but there are clear cores which can be defined. Under tolerance, prostitution is accepted as an inevitable phenomenon. This can either take the form of the absence of any regulation of prostitution, informal or de-facto regulation, or a political debate the outcome of which is that prostitution is not to be interfered with by the authorities. Historically the word "tolerance" has also been associated with the regulation ("French") system. This is not the way the term is used here.

Under regulation, there are written laws that regulate how prostitution is to be organized in the whole of a jurisdiction.

Under prohibition, the authorities make an effort to stamp out prostitution by criminalizing prostitutes, pimps, madams and/or brothels. When prostitution had been regulated, often the term abolition was used for its prohibition, even if technically the abolition movement might just have demanded that the state stop regulating the sex business, not prohibition (Conner, this volume, Paris).

Emancipation is the attempt not just to tolerate prostitution as a necessary evil, but to organize it as a viable career for women, and to stamp out forms of oppression often associated with prostitution.

Apart from emancipation, the other policies can be applied in a mix as different authorities deal with prostitution. While the official policy of a state may be that prostitution or activities related to it are unlawful and must be abolished, local police authorities may think it a preferable policy to tolerate prostitution in certain establishments or neighbourhoods as a better means of containing and supervising it, or profiting from bribes.

The periods for which the data are listed in the table were chosen based on changes in policy as suggested by the urban overviews. They have been retained in the graph. 